- Monogràfic -

\title{
“HUMANE THERIOCIDES": TRACES OF COMPASSION FOR ANIMALS IN THE NORWEGIAN LEGAL DISCOURSE ON ILLEGAL BEAR AND WOLF KILLINGS ${ }^{1}$
}

\author{
Martine S. B. Lie \\ Doctoral Research Fellow \\ Department of Criminology and Sociology of Law, University of Oslo \\ m.s.b.lie@jus.uio.no
}

Date of Reception: April 30 2021 / Date of Acceptance: June $4^{\text {th }} 2021$

\begin{abstract}
Wolves and brown bears are critically endangered in Norway. Their population is approximately 110 and 150 individuals, respectively, and is kept at these low numbers through licensed hunts. These animals are also vulnerable to illegal theriocides (killings of animals by humans), which poses a considerable threat to the species' survival. The theriocides also harm individual animal victims and impinge on their intrinsic value. This article assesses whether a consideration of harm to the individual animals is part of the Norwegian courts' problem definition and discourse order concerning such illegal hunts by developing and conducting a "critical green victimological discourse analysis" of verdicts. Moreover, the courts' portrayals of the victims are assessed-by asking the question: do they acknowledge them as such, or continue the speciesist ideology of the Anthropocene, seeing animals mainly as commodities and components of nature?
\end{abstract}

RESUM: Els llops i els óssos bruns estan en perill crític a Noruega. La seva població és d'aproximadament 100 i 150 individus, respectivament, i es manté en aquests nombres baixos mitjançant la cacera amb llicència. Aquests animals també són vulnerables als teriocides il-legals (la matança d'animals per part dels humans), que

\footnotetext{
${ }^{1}$ This study is produced as part of the project "Criminal justice, wildlife conservation and animal rights in the Anthropocene - CRIMEANTHROP" at the Department of Criminology and Sociology of Law, University of Oslo. It is funded by the granting Committee for the Humanities and Social Sciences (FRIPRO) of the Research Council Norway, project number 289285. I am grateful to Professors Nigel South, Ragnhild Sollund and two anonymous reviewers for their valuable comments to the article.
} 
suposa una amenaça considerable per a la supervivència de l'espècie. Els teriocides també perjudiquen les víctimes individuals animals i vulneren el seu valor intrínsec. Aquest article avalua si una consideració de dany als animals individuals forma part de la definició del problema dels tribunals noruecs i del seu ordre de discurs sobre aquestes caceres il-legals mitjançant el desenvolupament i la realització d'una «anàlisi crítica del discurs victimològic verd» dels veredictes. D'altra banda, avaluo les representacions que els tribunals fan de les víctimes preguntant: les reconeixen com a tals, o continuen amb la ideologia especista de l'Antropocè, veient els animals principalment com a mercaderies i components de la naturalesa?

RESUMEN: Los lobos y los osos pardos están en peligro crítico de extinción en Noruega. Su población es de aproximadamente 110 y 150 individuos, respectivamente, y se mantiene en estos números bajos mediante la caza autorizada. Estos animales también son vulnerables a los teriocidas ilegales (matanzas de animales por parte de los humanos), lo que supone una amenaza considerable para la supervivencia de la especie. Los teriocidas también perjudican a las víctimas individuales de los animales y afectan a su valor intrínseco. Este artículo evalúa si la consideración del daño a los animales individuales forma parte de la definición del problema y del orden del discurso de los tribunales noruegos en relación con dichas cacerías ilegales, desarrollando y llevando a cabo un "análisis crítico del discurso victimológico verde" de las sentencias. Además, se evalúa la representación de las víctimas por parte de los tribunales, planteando la siguiente pregunta: ¿las reconocen como tales o continúan con la ideología especista del Antropoceno, viendo a los animales principalmente como mercancías y componentes de la naturaleza?

KEY WORDS: Illegal hunts - endangered species - animal harm — species justice - large predators - legal discourse — critical discourse analysis

PARAULES CLAU: caça il-legal — espècies en perill d'extinció — danys als animals — justícia de les espècies - grans depredadors - discurs jurídic - analísi crítica del discurs

PALABRAS CLAVE: caza ilegal - especies en peligro de extinción — daño a los animales - justicia de las especies - grandes depredadores - discurso jurídico — análisis crítico del discurso 


\section{LIST OF CONTENTS:}

ABSTRACT; I. INTRODUCTION; II. CRITICAL GREEN VICTIMOLOGICAL DISCOURSE ANALYSIS; 1. CGVDA of verdicts on illegal bear and wolf theriocides; 2 . Why study courts' discourse of animal victimization?; III. DATA COLLECTION AND ANALYSIS; IV. THE CASES; V. (HOW) ARE THE VICTIMS AND THEIR SUFFERING PORTRAYED? 1. Portrayal of victims; 2. Consideration of suffering; 3. "Humane euthanasias" VI. CONCLUDING REMARKS

\section{INTRODUCTION}

Gray wolves and brown bears are critically endangered in Norway, with only 109-114 wolves recorded in the winter season 2020-2021 (including individuals shared with Sweden) and 150 bears in $2020 .^{2}$ The populations are monitored closely to ensure correct estimates of their size. Norway has international commitments through the Bern Convention to protect these animals, ${ }^{3,4}$ but regularly launches licensed hunts due to hunting and farming interests. These hunts are highly debated and have been challenged in court. ${ }^{5}$ The focus of this article is on the courts' dealings with illegal bear and wolf killings, which pose a considerable threat to the species' survival. ${ }^{6}$ Such killings also harm individual animal victims. Additionally, the killings ignore the victims' intrinsic value, accorded to all animals in The Animal Welfare Act (AWA) "independent of the utility they may have for humans." ${ }^{7}$ Acknowledging this, I use Beirne's ${ }^{8}$ term "theriocide" to describe the killings. Beirne suggests this word to describe all sorts of

\footnotetext{
2 ROVDATA. "Bjørn - Bestandsstatus" [Bear - Population status]. <https://rovdata.no/Brunbj\%C3\%B8rn/Bestandsstatus.aspx> [Retrieved 10.6.2021]; Rovdata. "Ulv Bestandsstatus" [Wolf - Population status]. <https://rovdata.no/Ulv/Bestandsstatus.aspx> [Retrieved 10.6.2021].

${ }^{3}$ COUNCIL OF EUROPE, Convention on the Conservation of European Wildlife and Natural Habitats, ETS No.104 (1979), <https://www.coe.int/en/web/conventions/full-list///conventions/treaty/104>. [Retrieved 10.3.2021]. Norway ratified the convention in 1986. Bears and wolves are listed as "strictly protected fauna species" in the convention's "Appendix II".

${ }^{4}$ As Beirne highlights, amongst others, the term "animal" creates an artificial divide between humans and all other animals. I still use the term here for simplicity. See PIERS BEIRNE, "Animal Rights, Animal Abuse and Green Criminology", in Piers Beirne and Nigel South (eds.), Issues in Green Criminology, Willan Publishing. Cullompton, 2007. (pp. 55-83)

${ }^{5}$ RAGNHILD SOLLUND, "Wildlife Management, Species Injustice and Ecocide in the Anthropocene", in Critical Criminology 28, no. 3, 2020. (pp. 351-369). <doi:10.1007/s10612-019-09469-1>.

${ }^{6}$ OLOF LIBERG ET AL., "Shoot, Shovel and Shut up: Cryptic Poaching Slows Restoration of a Large Carnivore in Europe", in Proceedings of the Royal Society B: Biological Sciences 279, no. 1730, 7 March 2012. (pp. 910-15). <doi:10.1098/rspb.2011.1275>

7 ANIMAL WELFARE ACT, LOV-2009-06-19-97, § 3. Translated version by the Government. $<$ https://www.regjeringen.no/en/dokumenter/animal-welfare-act/id571188/> § 12. [Retrieved 2.2.2021].

${ }^{8}$ PIERS BEIRNE, "Theriocide: Naming Animal Killing", in International Journal for Crime, Justice and Social Democracy 3, no. 2, 2014. (pp. 49-66). <doi:10.5204/ijcjsd.v3i2.174>.
} 
killings of animals by humans as an "honest" word, similar to "homicide." By introducing the term he aims to acknowledge the nature and seriousness of (legally or illegally) taking a life, regardless of the victims' species.

Through an analysis of recent verdicts regarding illegal bear and wolf theriocides or attempted such, I assess whether Norwegian courts acknowledge the individual harm caused by the crimes and the victims' intrinsic value. I also discuss what perceptions of and attitudes toward animal harm the courts' "problem definitions" of such theriocides reflect. This is done by merging critical discourse analysis (CDA) with green criminology's anti-anthropocentric and anti-speciesist harm-based perspective to conduct a "critical green victimological discourse analysis" (CGVDA) of the verdicts. I describe this method in the next part, and discuss the study's contribution to critical research on large predator hunts and animal harm in general. I then describe the data collection, coding, and cases. Following this, I present and analyze how the verdicts portray the animal victims and harm caused to them, finding three types of portrayals of the victims and limited consideration of animal harm. Finally, I offer some concluding remarks regarding the perspectives on animals represented by the discourses employed by the courts and the possible consequences of these discourses.

\section{CRITICAL GREEN VICTIMOLOGICAL DISCOURSE ANALYSIS}

CGVDA, as I suggest naming it, is an interdisciplinary combination of green criminology, specifically green victimology, ${ }^{9}$ and CDA. CDA is based on the assumption that discourse reflects and may contribute to creating, upholding or challenging oppressive social structures and ideologies, and therefore combines critical social science perspectives with linguistic discourse analysis. "Discourse" is defined in several ways in CDA, the most meaningful in this context being "a way to construct parts of the world that is associated with a certain societal perspective."11 By analyzing texts ${ }^{12}$ linguistically and as part of social practices and structures, CDA aims

\footnotetext{
${ }^{9}$ e.g. ROB WHITE, "Green Victimology and Non-Human Victims", in International Review of Victimology 24, no. 2, 2018. (pp. 239-55). <doi:10.1177/0269758017745615>.

10 e.g. MARIANNE WINTHER JØRGENSEN and LOUISE PHILLIPS, Diskursanalyse som teori og metode [Discourse analysis as theory and method]. Roskilde Universitetsforlag. Fredriksberg, 1999.

11 JOAR SKREDE, Kritisk Diskursanalyse [Critical Discourse Analysis]. Cappelen Damm akademisk. Oslo 2017. p. 26, My translation.

12 Understood broadly. One can also analyze talk or three-dimensional expressions with CDA, see e.g. SKREDE, Kritisk Diskursanalyse, cit..
} 
to reveal how discourses contribute to creating or reproducing repressive ideologies, with the normative goal of reducing oppression. ${ }^{13}$ This makes it a well-suited research method for green criminology, a tradition firmly placed within critical criminology. ${ }^{14}$ Central to critical criminology is the normative quest to uncover harms to, and unfair power distributions on behalf of marginalized groups in society. ${ }^{15}$ Herein, green criminology extends the victimological scope of "victim" to include nature and animals other than humans. ${ }^{16}$ I thus expand CDA's framework for uncovering (re)production of repression through discourse by including the extended green victimological scope, and name the approach CGVDA.

\section{CGVDA of verdicts on illegal bear and wolf theriocides}

Fairclough ${ }^{17}$ has developed a comprehensive framework for CDA. My study is not a full-scale "Faircloughian" analysis, but it is inspired by his work and emphasizes certain aspects of his model. I do not focus on linguistic micro-analysis of the verdicts, for four reasons: First, the limited space herein does not allow for a full-scale detailed analysis of the verdicts employing all the components of Fairclough's framework. Second, many linguistic traits of the verdicts probably result from institutional norms of the genre (formal, sober language with nominalizations and long sentences, structured after a template ${ }^{18}$ ) and not the judges' perception of the animals and animal harms as such. Legal discourse is indeed an interesting and evolving research field,,${ }^{19}$ but my focus is not on the general linguistic traits of verdicts. Third, a detailed linguistic analysis risks being fallacious, as the verdicts are written in Norwegian and employ several technical terms regarding both law and hunting that are not directly translatable to English, (a

\footnotetext{
${ }^{13}$ e.g. JØRGENSEN AND PHILLIPS, Diskursanalyse som teori og metode, cit.

${ }^{14}$ e.g. RAGNHILD SOLLUND, "Introduction: Critical Green Criminology - An Agenda for Change", in Ragnhild Sollund (ed.) Green Harms and Crimes: Critical Criminology in a Changing World. Palgrave Macmillan UK. Basingstoke, 2015. (pp. 1-26). <doi:10.1057/9781137456267>.

${ }^{15}$ e.g. SOLLUND, "Introduction: Critical Green Criminology..." cit.

${ }^{16}$ e.g. NIGEL SOUTH, "Green Criminology: Reflections, Connections, Horizons", in International Journal for Crime, Justice and Social Democracy 3, no. 2, 2014. (pp. 5-20). <doi:10.5204/ijcjsd.v3i2.172>; BILL MCCLANAHAN and AVI BRISMAN, "Green Criminology for Social Sciences: Introduction to the Special Issue", in Social Sciences 9, no. 10. 2020. (pp. 1-4). <doi:10.3390/socsci9100170>.

17 e.g. FAIRCLOUGH, Analysing Discourse, cit..

18 DONATA BERŪKŠTIENĖ, "Legal Discourse Reconsidered: Genres of Legal Texts", in Comparative Legilinguistics 28, 2016. (pp. 92-119). <doi:10.14746/cl.2016.28.5>; ESPEN INGEBRIGTSEN, "Talepresentasjon i straffedommer" [Speech presentation in penal sentences], in Tidsskrift for Rettsvitenskap 132, no. 5, 2019. (pp. 443-490). <doi: 10.18261/issn.1504-3096-2019-05-02>.

${ }^{19}$ e.g. BERŪKŠTIENĖ, "Legal Discourse Reconsidered..." cit.
} 
well-known challenge of legal discourse studies). ${ }^{20}$ Fourth, the body of verdicts is considerable-181 closely-written pages, and therefore better suited to assessing prominent discourses than to microanalysis of syntax and punctuation.

The focus here is on the verdicts' representations of the animal victims and suffering inflicted on them, hence what discourses they employ in that regard. I will also discuss the possible effects of the detected discourses and how they reflect and contribute to what Fairclough calls "social structure", as he sees this as an important part of CDA. ${ }^{21}$ The social structure in question here is the Anthropocene-the current humancentered era where nature and animals are valued and "managed" from human interests and point of view. ${ }^{22}$ In this era, an oppressive ideology is speciesismhumans' discrimination against other animals and differentiation between them, often according to their utility to humans. ${ }^{23}$ Anthropocentrism and speciesism enable the large-scale exploitation of animals in Western societies, and even systematic killing of animals for food and recreational purposes, such as in legal hunts. This social structure and ideology are engraved in legislation, which mostly regulates nature according to human interests (including interests in conservation), protecting humans' use of animals and nature. ${ }^{24}$ For example, animal welfare legislation often mandates weighing harms caused to animals against the harm's "necessity" for humans, where human interests are privileged. ${ }^{25}$ Anthropocentrism and speciesism also affect the perception

\footnotetext{
${ }^{20}$ e.g. BERŪKŠTIENĖ, "Legal Discourse Reconsidered..." cit.

21 The terms "social events," "social practice," and "social structure" reflect Fairclough's updated framework for CDA (introduced in Fairclough, Analysing Discourse, cit.). These replace his former threestep model (text-discursive practice-social practice), which might be more familiar to some readers.

22 E.g. MORTEN TØNNESEN, "Menneskeveldet: antropocen - menneskets tidsalder" [The human reign: the Anthropocene - the era of humans], in Ragnhild Aslaug Sollund, Guri Larsen, and Morten Tønnesen (eds.), Hvem er villest $i$ landet her?: råskap mot dyr og natur $i$ antropocen, menneskets tidsalder. Scandinavian Academic Press. Oslo, 2013. (pp. 47-56); see also AVI BRISMAN and NIGEL SOUTH, "Green Criminology and Environmental Crimes and Harms", in Sociology Compass 13, no. 1, 2019. (pp. 1-12). <doi:10.1111/soc4.12650>.

${ }^{23}$ e.g. MARTINE S. B. LIE and RAGNHILD SOLLUND, "Speciesism and Theriocide", in Avi Brisman, Eamonn Carrabine and Nigel South (eds.) The Routledge Companion to Criminological Theory and Concepts. Routledge. Abingdon, 2018. (pp. 386-90). <doi:10.4324/9781315744902-86>; RAGNHILD SOLLUND, "Speciesism as Doxic Practice Versus Valuing Difference and Plurality", in Rune Ellefsen, Ragnhild Sollund and Guri Larsen (eds.), Eco-Global Crimes: Contemporary Crimes and Future Challenges. Ashgate, Farnham, 2012. (pp. 91-115).

24 e.g. RUNE ELLEFSEN, Med lov til å pine: Om bruk og beskyttelse av dyr. [With license to torment: On use and protection of animals]. Fritt forlag / Inspirator forlag. Oslo, 2013; GARY L. FRANCIONE, Animals as Persons: Essays on the Abolition of Animal Exploitation. Columbia University Press. New York, 2008; GURI LARSEN, "Dyr Og Natur Som Menneskets Eiendom" [Animals and Nature as Humans' Property], in Materialisten 41, no. 3, 2014. (pp. 27-45).

${ }^{25}$ e.g. ELLEFSEN, Med lov til å pine, cit.; FRANCIONE, Animals as Persons, cit.
} 
of animals as victims of harms-they are not what Christie ${ }^{26}$ termed "ideal victims" because "they are not sufficiently powerful to make their case known, and successfully claim their status of ideal victims." 27 This is the point of departure for this analysis, aiming to see whether the courts challenge or maintain the speciesist perceptions of animals as "non-victims" when passing sentences for illegal wolf and bear theriocides. Following this, I search for signs of species justice in the verdicts, which is one of three prominent justice stances in green criminology: a human-oriented environmental justice perspective, ecosystem-based ecological justice perspective, and animalcentered species justice perspective. ${ }^{28}$ White describes "species justice" as concerned with harm toward "non-human animals and their intrinsic right not to suffer abuse, whether this be one-on-one harm, institutionalized harm or harm arising from human actions that affect climates and environments on a global scale." ${ }^{29}$ Here, it is understood as a concern for individual animals and protection of or advocacy for (some of) their interests. In the words of Brisman and South, as "treating nonhumans who are harmed as victims." ${ }^{30}$ Even though they are accorded intrinsic value, animals do not hold substantial rights in Norwegian law, only protection from "unnecessary suffering". ${ }^{31}$ As is typical for animal welfare legislation, the AWA allows for infliction of harm and death to animals, as long as the suffering is seen as "necessary" from a human point of view. ${ }^{32}$ Practices such as recreational hunting show that the threshold for necessity is set low. Thus, judges have limited room for making rights-based evaluations. Therefore, species justice here includes discourses of animal welfare-a utilitarian perspective looking to minimize animal suffering, with no absolute rules condemning infliction of pain or death. ${ }^{33}$

\footnotetext{
${ }^{26}$ NILS CHRISTIE, "The Ideal Victim", in Ezzat A. Fattah (ed.), From Crime Policy to Victim Policy: Reorienting the Justice System, Palgrave Macmillan UK. London 1986. (pp. 17-30). <doi:10.1007/9781-349-08305-3_2>.

${ }^{27}$ SOLLUND, "Speciesism as Doxic Practice..." cit. p. 103.

${ }^{28}$ E.g. ROB WHITE, "The Foundations of Eco-Global Criminology", in Rune Ellefsen, Ragnhild Sollund, and Guri Larsen (eds.), Eco-Global Crimes: Contemporary Problems and Future Challenges. Routledge. Farnham, 2012. (pp. 15-33); BRISMAN and SOUTH, "Green Criminology ... cit.".

${ }^{29}$ WHITE, "The foundations of Eco-Global Criminology", cit. p. 27.

${ }^{30}$ BRISMAN AND SOUTH, "Green Criminology..." cit. p. 6, emphasis original.

${ }^{31}$ ELLEFSEN, Med lov til å pine, cit.

${ }^{32}$ ELLEFSEN, Med lov til å pine, cit.; ANIMAL WELFARE ACT, cit. § 3.

${ }^{33}$ PIERS BEIRNE, "Animal Rights..." cit.; PETER SINGER, Animal Liberation. Thorsons. London 1991.
} 


\section{Why study courts' discourse of animal victimization?}

This is not the first green criminological study of verdicts from cases of illegal large predator theriocides, but the focus and method is new. Sollund ${ }^{34}$ has analyzed such verdicts from Norwegian courts. Her selection of verdicts is mostly older than that gathered here, while my sample only includes verdicts passed after the AWA, including the intrinsic value, was enacted in 2009. Moreover, while commenting on the courts' evaluations, Sollund's focus is largely on the acts and the harms caused, employing a species justice perspective more concerned with animal rights than that employed here. She also problematizes legal hunts, while I focus solely on illegal theriocides.

I contend that it is important to understand the legal discourse order of illegal large predator theriocides and the courts' role in reproducing and potentially challenging speciesist attitudes leading to animal victimization: Courts are significant in defining the discourse order of a theme (for example illegal wolf and bear theriocides) due to their authority and power to issue formal punishments, and by being a source of law when setting precedent. Verdicts also constitute a "genre of governance,"35 in the sense that they are institutional texts governing, in this instance, the social practice of wolf and bear theriocides, by evaluating local events against national legislation. Judges (particularly those on the Supreme Court) are, indeed, appointed to have "final say" in how matters of the law are to be understood and sanctioned. Therefore, assessing how they frame the illegal victimization of bears and wolves is of utmost concern. As explained above, a broader species justice perspective is necessary for such an analysis to be meaningful.

The verdicts result from the social events of the trials in which the social events of the (attempted) theriocides were recontextualized by the lawyers and evaluated by the judges according to judicial norms. ${ }^{36}$ Various texts and viewpoints about the killings and how they should be adjudicated are presented to the court during a trial (such as

\footnotetext{
34 e.g. RAGNHILD SOLLUND, "With or without a License to Kill: Human-Predator Conflicts and Theriocide in Norway", in Avi Brisman, Nigel South and Rob White (eds.) Environmental Crime and Social Conflict. Contemporary and Emerging Issues. Ashgate, Farnham 2016. (pp. 95-124); RAGNHILD SOLLUND, "The Animal Other: Legal and Illegal Theriocide", in Matthew Hall, Jennifer Maher, Angus Nurse, Gary Potter, Nigel South, and Tanya Wyatt (eds.), Greening Criminology in the 21st Century: Contemporary Debates and Future Directions in the Study of Environmental Harm. Routledge. London, 2017. (pp. 79-99); SOLLUND, "Wildlife Management, Species Injustice..." cit.

${ }^{35}$ FAIRCLOUGH, Analysing Discourse, cit. p. 32.

${ }^{36}$ AUDUN KJUS, "Homo narrans i strafferetten" [Homo narrans in criminal law], in Kritisk Juss 32, no. 3, 2006. (pp. 254-258). <doi: 10.18261/ISSN2387-4546-2006-03-08>; INGEBRIGTSEN, "Talepresentasjon i straffedommer", cit.
} 
evidence reports, witness statements, prior verdicts, and legislation). The judges evaluate and "filter" 37 these representations according to their profession's "recontextualizing principles" 38 when they author the verdicts, and determine which (parts) of the representations are relevant for the conviction. ${ }^{39}$ They are restricted by legislation, judicial norms, and conventions of the verdict genre, but non-judicial 'common sense' is also a considerable part of Norwegian verdicts, leaving the judges room for agency and discretion. ${ }^{40}$ Moreover, penal cases are judged by a combination of judges and lay judges in the Norwegian district and appeal courts, ${ }^{41}$ likely increasing the possibilities for such non-judicial discretion. What is of interest here is, however, not specific judges' discourses from a micro-perspective, but how the courts, as defining institutions in society, represent individual animal crime victims and harm done to them.

As is common for Norwegian verdicts and pointing to their role of setting precedent, the judges frequently reference and include excerpts from earlier, similar verdicts in the verdicts analyzed here. This intertextual characteristic also indicates their power in (re)producing discourse: If the verdicts analyzed here ignore or downplay the suffering caused to the animal victims, this influences later cases, since the judges of new cases will look at and reference former relevant verdicts when they make their decisions. Prosecutors also orient themselves according to the "appropriate" discourses communicated in relevant verdicts when preparing and pleading their cases. In this way, verdicts establish and reproduce a relatively stable legal discourse order for the issue in question.

\section{DATA COLLECTION AND ANALYSIS}

The data consist of 11 verdicts covering six theriocides or attempted such. Nine of the accused were found guilty of breaching either the Nature Diversity Act (NDA) $\S 15$ or the Penal Code $\S 152 b / 240$ (pre/post 2015) for harming or killing wolves or bears

\footnotetext{
37 FAIRCLOUGH, Analysing Discourse, cit. p. 34.

${ }^{38}$ FAIRCLOUGH, Analysing Discourse, cit. p. 139.

39 KJUS, "Homo Narrans..." cit.; INGEBRIGTSEN, "Talepresentasjon i straffedommer" cit.

40 SOLVEIG LAUGERUD, "Common Sense, (Ab)Normality and Bodies in Norwegian Rape Verdicts", in NORA - Nordic Journal of Feminist and Gender Research 28, no. 1, 2020. (pp. 18-29). <doi:10.1080/08038740.2019.1697748>.

${ }^{41}$ Until recently, some appeal court cases were jury trials. The Parliament abolished juries in 2017, with the last jury trial conducted in 2019 . None of the cases in this study were tried before a jury.
} 
without permission, or attempting to do so..$^{42}$ One was acquitted, as his involvement in a planned hunt was not proven beyond doubt. Five of the verdicts are from four different district courts. Four of the cases were granted an appeal in the same Appeal Court, and one of these was subsequently appealed and decided in the Supreme Court. Following the Supreme Court decision, the case of one of those convicted was sent back to the Appeal Court for sentencing. This case included both the planned hunt, carried out by a group of hunters, and a wolf theriocide committed by one of them. I collected the verdicts from "Lovdata," a semi-open Norwegian database with anonymized versions of all recent verdicts from appeal courts, the Supreme Court, and some verdicts from district courts. ${ }^{43}$ The sample includes all relevant verdicts found when searching for verdicts from when the AWA and NDA were enacted in 2009 until 2019, mentioning the Norwegian words for wolf/ves, bear(s), lynx, and wolverine(s). ${ }^{44}$ I also examined all verdicts mentioning the Bern Convention, the NDA, the Wildlife Act, the Predator Regulation, or the Penal Code $\S 152 b / 240$, in case I missed any relevant cases in the first search. This legislation regulates large predator conservation, management, and hunting in Norway. Three additional verdicts were gathered directly from district courts. I found no verdicts regarding theriocides of lynx or wolverines, curiously contrary to Sollund's ${ }^{45}$ sample of verdicts. Verdicts from two bear theriocides were excluded as the theriocides happened before the AWA was enacted.

To analyze discourses in texts, Fairclough suggests that one identify "the main parts of the world (including areas of social life) which are represented - the main themes" and "the particular perspective or angle or point of view from which they are represented." 46 I follow his model here, though focusing on the parts of the verdicts describing the animal victims and their harm, including where such descriptions are missing. The data were adjusted to a manageable size for qualitative CGVDA by reading through the verdicts and coding parts that were or could be relevant for the analysis in NVivo. Such relevant parts were, for example, descriptions of the (attempted) theriocides and parts where the judges in any way described the animals or evaluated whether or how the shots had harmed them. I subsequently coded these

\footnotetext{
${ }^{42}$ Most of them were also found guilty of breaching weapon regulations.

${ }^{43}$ One needs a subscription to access all available verdicts. A subscription is available to everyone affiliated with the Faculty of Law at the University of Oslo.

44 "Ulv", "bjørn*", "gaupe*" and "jerv".

${ }^{45}$ e.g. SOLLUND, "With or without a License..." cit.

${ }^{46}$ FAIRCLOUGH, Analysing Discourse, cit. p. 129.
} 
parts in sub-codes according to how they presented the issues, thereby identifying the angle from which they were represented. The sub-codes formed a preliminary basis for distinguishing the different discourses in the material.

Illustrative excerpts from the verdicts are included in the presentation of the analysis to ensure transparency. I have translated the excerpts from Norwegian, but base the analysis itself on the original Norwegian text. As mentioned above, translating legal discourse has its limitations due to nation-specific institutional language. I have sought to translate the excerpts as directly as possible, while maintaining the meaning. Concrete words highlighted in the analysis are directly translatable with the same meaning in both languages, when nothing else is remarked upon.

\section{THE CASES}

Although the verdicts do not always highlight the harm caused to the animals, their representations of the cases offer at least some insights into this. I present the representations here to provide a basis for assessing whether and how the courts evaluated the harm. The presentation is unavoidably my representation of the judges' representations. However, following Fairclough's critical realist perspective, ${ }^{47}$ the (attempted) theriocides are real incidents, not discursive constructs, and their characteristics are not discursive, even though their representation is. The presentation will therefore focus on the descriptions of actual events, as far as the verdicts provide such descriptions.

The (attempted) killings can be divided into three categories: (a) a planned, collaborative hunt, (b) "defensive," and (c) accidental (attempted) theriocides. In the planned hunt $\left(\mathrm{a} 1^{48}\right)$, a network of hunters monitored, hunted, and shot at a family of three wolves, with the intention of killing them to reduce the wolf population. The wolves escaped the bullets without any known physical harm.

In two cases, the defendants argued that they killed two wolves in defense of their animals. In another case, the defendant claims he shot at a bear to avoid being attacked. Defensive theriocides may be legal if required to stop immediate or ongoing

\footnotetext{
${ }^{47}$ FAIRCLOUGH, Analysing Discourse, cit.; see also SKREDE, Kritisk Diskursanalyse, cit. 48 TSOST-2014-168573, LE-2015-83191, HR-2016-1857-A, LE-2016-182913.
} 
attacks ${ }^{49}$ but the courts concluded that none of the cases met these criteria. In the first case $\left(b 1^{50}\right)$, a one-year-old male wolf was shot, allegedly to protect the defendant's sheep, from a distance of approximately 84 meters when seen heading for the sheep, around $25 \mathrm{~m}$ from their enclosure. The bullet hit him behind his right shoulder, and he "died almost instantly," according to the verdict. ${ }^{51}$ Another defendant shot and wounded a male bear whom he thought was about to attack him, after the bear had scared his girlfriend's horses so that they broke out of their enclosure (b2 $\left.{ }^{52}\right)$. He said he meant to fire a warning shot at a distance of 7-10 $\mathrm{m}$ from the bear, but thought he accidently hit him. However, the judges concluded that he did not hit him with the first shot. The bear ran away, and the defendant followed him and shot two more shots from a 20-25 m distance, allegedly in order to kill him, as he thought he was hurt by the first shot. These shots hit the bear, leaving him with 22 pellets encapsulated in his posterior and genitalia, as the defendant used unsuitable ammunition. The bear was shot and killed legally eight months later. In the last "defensive" theriocide $\left(\mathrm{b}^{53}\right)$, the defendant shot a male wolf from a distance of about $34 \mathrm{~m}$, claiming to hinder him from attacking his dog. The dog was, however, not to be seen when the wolf was shot, and the wolf did not show signs of aggression toward her/him. The shot hit the wolf in the heart, and he started to walk away but died shortly afterwards.

The third type of cases concerns an illegal wolf theriocide $\left(\mathrm{c}^{54}\right)$ and an attempted such $\left(\mathrm{c} 2^{55}\right)$, claimed by the accused to be accidents. In the first case, the theriocider-also the instigator of the planned wolf hunt-claimed to have mistakenly thought the wolf was a fox when shooting him during an overnight fox hunt. ${ }^{56}$ In the second case, the defendant claimed that he mistakenly thought the hunting season for wolves had started when shooting a passing wolf while sitting on stand on an elk hunt. Neither of the wolves was killed straight away. The wolf allegedly thought to be a fox suffered for around six hours from the first shot, which collapsed his lungs and damaged his spine, until the defendant checked on him and fired two more shots, now fatal. The defendant

\footnotetext{
49 NATURE DIVERSITY ACT, LOV-2009-06-19-100 § 17. Translated version by the Government. $<$ https://www.regjeringen.no/en/dokumenter/nature-diversity-act/id570549/>. [Retrieved 5.3.2021].

50 TOVRO-2012-30478.

51 TOVRO-2012-30478, p. 4, my translation.

52 THEDM-2012-51106, LE-2012-108373.

53 TSOST-2016-183971, LE-2017-6392.

54 TSOST-2014-168573, LE-2015-83191, HR-2016-1857-A, LE-2016-182913.

55 TSGUD-2019-6961, LE-2019-148163.

${ }^{56}$ Calling this a hunt is in reality misleading. The defendant did not hunt the foxes per se, but waited in a cabin overlooking bait he had put out to shoot foxes who came to eat.
} 
waited before checking on him, as he did not want to scare away other potential prey. The other wolf survived the shot, but "there were found trails of blood and other traces from the wolf over a distance of several kilometers." ${ }^{57}$

\section{V. (HOW) ARE THE VICTIMS AND THEIR SUFFERING PORTRAYED?}

This part combines textual analysis of the verdicts and identification of the discourses employed. First, I analyze the presentation of the animal victims, and then the evaluation of the harm caused to them. I focus on formulations chosen to describe and evaluate the victims and their suffering, whether the judges acknowledge their intrinsic value, and what discourse(s) they include and omit from the discursive order.

\section{Portrayal of victims}

The verdicts differ in how they describe the animal victims. Five of the verdicts do not describe the victims at all, other than stating what type of animal was shot, and in one case, that the victim had been registered in both Norway and Sweden. None mention the victims' intrinsic value according to the AWA. Six verdicts still include more or less detailed descriptions of the victims and the significance of their deaths. The descriptions separate into three types, portraying the victims as either (a) important or (b) insignificant for the populations' survival, or (c) as a "problem individual".

The District Court describes the wolf shot allegedly in defense of the defendant's dog (b3) as "genetically valuable," citing the DNA analysis: "The wolf was of FinnishRussian origin and is defined as a genetically valuable wolf. If the wolf had found a mate and bred, it would have added new genes to the Scandinavian wolf population, which suffers from inbreeding." ${ }^{58}$ The Appeal Court describes him the same way. When stating that the wolf was valuable, this frames the killing as severe. However, it is not related to the wolf's intrinsic value, but to his potential for improving the DNA of the wolf population. The focus on inbreeding is neither motivated by reducing animals' suffering from it, ${ }^{59}$ but rather by the goal of survival of the population when kept in small numbers. It thereby reflects a species conservation discourse, focusing on whether the

\footnotetext{
57 TSGUD-2019-69611, p. 3, my translation.

58 TSOST-2016-183971, p. 8, my translation.

${ }^{59}$ Some of the suffering caused to the animals by the inbreeding is described in JANNIKKE RÄIKKÖNEN ET AL., "What the Inbred Scandinavian Wolf Population Tells Us about the Nature of Conservation", in PLOS ONE 8, no. 6, 2013. (pp. 1-7). <doi:10.1371/journal.pone.0067218>.
} 
killing significantly impacts the species' viability, rather than a species justice perspective.

No other victims are characterized as "genetically valuable" by the courts. However, the District Court describes the planned wolf hunt (a1) as threatening the species' survival due to the female wolf's reproductive capacity:

By hunting a female wolf that bleeds, one does not only impact the individual, but effectively obstructs the offspring that could have resulted from a breeding, thereby affecting the local population and the possibility of reaching the population goal. It therefore takes time to compensate for the loss of this individual, for example, by another animal possibly replacing its role, as one sees with replacement of individuals in a territory after another individual disappears. ${ }^{60}$

Although the attempted theriocide is described as a loss if it had succeeded, the emphasis is not on the loss of life for the victim, but on her importance as a component in the overall population and for reaching the management goal. The explicitly articulated view that she can be replaced in time also directly ignores her intrinsic value. Moreover, the Appeal Court reaches a different conclusion than the District Court regarding her value when evaluating the effect if she and her family had been killed: “... a possible culling of the three wolves would not conceivably increase the risk of extinction of the Norwegian part of the wolf population." 61 The wolf hunt could have killed a whole family at once, including a young wolf with many years to live, but the court does not offer this a comment: What matters is the wolves' significance for the general population's survival, in which they are found to be insignificant. Not only does this excerpt represent the species conservation discourse, but also how several verdicts portray the victims of the (attempted) theriocides as insignificant. This includes the verdicts neglecting to describe the victims at all, portraying them as insignificant by their exclusion.

Regarding the wolf killed during the fox hunt (c1), the District Court says:

It carries with it genes that otherwise occur in small numbers, but is not covered by the agreement with Sweden on protecting genetically valuable puppies (only concerning the first generation). It is clear that the culling of this male wolf would not have a mentionable negative impact on, for example, the inbreeding situation. ${ }^{62}$

Again, the focus is on the wolf's genetic value, not his individual interests and intrinsic value. Even when his genes are described as rare, he is not seen as valuable. Nor is

\footnotetext{
60 TSOST-2014-168573, p. 18, my translation and emphasis.

61 LE-2015-83191, p. 12, my translation.

62 TSOST-2014-168573, p. 17, my translation.
} 
he covered by a transnational agreement with Sweden to protect the puppies of immigrant wolves from the Finnish-Russian population, as he is "only" a descendant of such a wolf. Here, we see another argument for his insignificance besides genetics: transnational politics. As he is not protected by a transnational agreement, this adds to his "unimportance"-his death does not complicate the fulfillment of the agreement. The concern may, in reality, be as much with diplomacy and foreign affairs as with species survival.

Contrary to the above cases, the bear who was shot in self-defense (b2) is not solely described and evaluated as a component of the general population. Such an evaluation of his significance is made, but the Appeal Court also portray him as a 'problem individual':

The bear was approaching residential areas, and rummaging around in trash bins at the defendant's house and in his neighborhood. Bear footprints were observed in the area. The bear had also attempted to beat his way into a sheepcote. It later turned out that a culling license had been issued for the bear as a consequence of its behavior. ${ }^{63}$

This verdict is the only one describing other characteristics of the victim than physical and genetic attributes, acknowledging him as an individual with personality. However, the description is not favorable to him, but leaves the impression that he was a troublesome individual, not worth living, as he was to be killed legally. The court indeed adds that his personality is a mitigating circumstance. He is not unique this way either, as the court further states about young male bears: "These have a less important role in the species management, and can develop into problem animals, as in this case."64 This portrayal builds on the perception and discourse of large predators as dangerous, stating directly that these male bears are "problematic." In addition, the first part of the sentence places them in the above category of "insignificant" individuals, unimportant for the population's survival. Again, the species conservation discourse prevails.

The verdicts generally communicate that the victims' "genetic value" is what matters, not their intrinsic value. This is a finding shared by Sollund, who states, "nonhuman animals are protected not for who they are, but only for what they are - part of a protected species." ${ }^{65}$ The wolves and bears are presented as "components" of nature,

\footnotetext{
63 LE-2012-108373, p. 4, my translation.

64 LE-2012-108373, p. 6, my translation.

${ }^{65}$ SOLLUND, "With or without a License..." cit. p. 116, emphasis original.
} 
to be managed by humans. Due to this lack of consideration for individual animal victims, the verdicts maintain the speciesist perspective on animals as "non-victims." Not only are they neglected as victims of legal, systematic harms, ${ }^{66}$ but when they are victims of illegalities, they are only conditionally acknowledged as such by the courts. As can be seen from the excerpts, the verdicts also consistently refer to the victims as "it," objectifying them, instead of referring to them as the individuals they are-"she" and "he." 67 This is despite in-depth knowledge of these individuals owing to the surveillance of the populations. Non-personal language is however the norm for verdicts in general, as a measure to signalize impartiality. ${ }^{68}$ Moreover, as exemplified by the excerpts here, courts usually describe cases with "a high degree of abstraction [and] few adjectives," 69 not only when the victims are animals. A comparison of discourse in verdicts regarding crimes against animals and similar crimes against humans would be an interesting future endeavor.

The verdicts that do not describe the victims at all indicate that perceiving animals as victims is not readily a part of the legal discourse order of illegal large predator hunts. So do the verdicts describing the victims as "genetically invaluable"-implying that the (attempted) theriocides would only have victimized them, or rather their population, if they had different-"valuable"-DNA. Where description of the victims is lacking, the courts may have seen it as unnecessary if none of the parties in the case claimed that the victims were important to the species' survival. Effectiveness is indeed an important virtue for judges, leading them to limit themselves to evaluations they see necessary when authoring verdicts. ${ }^{70}$ The differences in the courts' description of the victims may of course result from individual differences between the judges as well. However, it rather seems to be a result of the discourse order set by former verdicts, clearly signaling that the only relevant description of victims of illegal large predator theriocides is their importance for the species' survival. An exception is the Appeal Court's comment on the personality of the bear in case b2, which they see as mitigating for the

\footnotetext{
${ }^{66}$ SOLLUND, "Speciesism as Doxic Practice..." cit.

${ }^{67}$ BEIRNE, "Animal Rights ..." cit.

68 INGEBRIGTSEN, "Talerepresentasjon i straffedommer" cit.

69 INGEBRIGTSEN, "Talerepresentasjon i straffedommer" cit. p. 454. My translation.

70 HANS PETTER GRAVER, "Vanlig juridisk metode? Om rettsdogmatikken som juridisk sjanger" [Ordinary legal method? On legal dogmatics as a legal genre], Tidsskrift for Rettsvitenskap 121, no. 2, 2008. p. 155 <doi: 10.18261/ISSN1504-3096-2008-02-01>; INGEBRIGTSEN, "Talerepresentasjon i strafferetten" cit. p. 451.
} 
sentence. As we shall see next, this verdict also stands out when evaluating the victim's suffering, which may be explained by the indictment.

\section{Consideration of suffering}

Based on her analysis of mostly older verdicts regarding illegal large predator theriocides, Sollund concludes: "Nowhere in any of the verdicts is there any consideration for the animals' own interest in living (...) and only seldom is there any mention of the pain and suffering caused by the theriociders." 71 While my data confirms her first finding, the second must be modified. The judges do evaluate the victims' suffering in some way in six of the verdicts, covering three of the cases. These evaluations only amount to approximately two and a half pages in total and are typically short descriptions of the shots and whether the victims died immediately or not.

Regarding the wolf shot in defense of sheep (b1), the court says: "The defendant shot the wolf, for which he knew he did not have a culling license, intentionally. He explained that he knowingly shot to euthanize the wolf humanely. The wolf died practically instantly after the projectile hit."72 When stating that the wolf died quickly, the court indirectly refers to an assumption that theriocides where animals die immediately are unproblematic and do not cause them suffering. By this, we can deduce that they do not consider the defendant's killing of the wolf as a problem per se, but rather that he killed him without a license. Moreover, the short comment above is the only one where the judges offer any (indirect) evaluation of the victim's suffering in the verdicts from cases where the victims died immediately. Such an evaluation seems to be on the outskirts of the discursive order, as long as the victims do not survive the shotsparadoxical from an animal rights perspective that sees death as "the ultimate form of deprivation."73

The judges comment on the victims' suffering more directly in two of three cases where the victims were hurt but did not die immediately. The District Court criticizes the theriocider shooting the wolf during the fox hunt (c1):

The Court finds that it is aggravating that the defendant during the hunt shot and wounded the wolf so that it was standing in a pit suffering until the next morning. In the Court's view, he had sufficient time to comply with the Wildlife Act $\S 19$ on

\footnotetext{
71 SOLLUND, "With or without a License..." cit. p. 115, reference to further reading omitted.

72 TOVRO-2012-30478, p. 6, my translation and emphasis.

${ }^{73}$ BEIRNE, "Animal Rights ..." p. 70.
} 
humane hunting, namely to ascertain that the animal is not exposed to suffering, before he pulled the trigger. ${ }^{74}$

Neither here is the "taking of a life" problematized or considered suffering, but rather the fact that it is not done properly. The court assumes that it is possible to kill animals without causing them to suffer, by indirectly stating that the defendant should have ascertained that the victim was not exposed to suffering when killed. The Appeal Court does not comment on the wolf's suffering at all, while the Supreme Court passively describes "After the culling the wolf was lying injured in a pit for the rest of the night, before A euthanized the animal after daybreak." ${ }^{75}$ The District Court thus places more emphasis on the wolf's suffering than the higher courts more likely to set precedent. However, both the Appeal and Supreme Court comment on the potential suffering of the wolves escaping the planned hunt (a1), treated in the same verdicts. The Supreme Court says, more elaborately this time: "It is aggravating that he also fired multiple shots in the direction of the three wolves at a far too long range-about 400 meters. The risk of harm and unnecessary suffering was considerable." ${ }^{76}$ Again, we see that it is not the attempted killing that is criticized as potential suffering, but the way it is done.

In the same case, the District Court expresses compassion for dogs potentially attacked by wolves in greater depth than for the wounded wolf: "Hunting with loose dogs, or at all releasing a dog where wolves are present can easily mean the end of the dog, with animal suffering and emotional human and material loss following."77 Paradoxically, the words chosen to describe the potential harm to the dogs are more emotional than those chosen to describe the wounded wolf's actual suffering. This might be explained by the different status of dogs and wolves-despite being close relatives, wolves are considered a problematic and potentially fearsome species, ${ }^{78}$ while dogs are "humans' best friends." If dogs die, this leads to "emotional loss," while wolves may be killed so long as they die quickly and are shot on a license. This is an expression of speciesist attitudes in the Anthropocene. Moreover, when the court calls a dead dog "material loss," this is an expression of the speciesist objectification of domesticated animals as human property. ${ }^{79}$

\footnotetext{
74 TSOST-2014-168573, p. 65, my translation and emphasis.

${ }^{75}$ HR-2016-1857-A, p. 10, my translation.

${ }^{76}$ HR-2016-1857-A, p. 10, my translation.

77 TSOST-2014-168573, p. 53, my translation and emphasis.

${ }^{78}$ HELENE FIGARI and KETIL SKOGEN. "Social representations of the wolf", in Acta Sociologica 54, no. 4, 2011. (pp. 317-332).

${ }^{79}$ E.g. BEIRNE, "Animal Rights ..." cit.; SOLLUND, "Speciesism as Doxic Practice..." cit.
} 
As with the wolf above, the harm caused to the bear in case b2 is mentioned sparingly by the District Court, focusing on the defendant's irresponsible actions rather than the harm to the victim: "It appears irresponsible to fire a shotgun at an animal as large as a bear and thereafter hunt what you think is a shot and wounded bear." ${ }^{80}$ This however changes in the Appeal Court verdict, which directly addresses the harm several times, as in this excerpt:

... the Court of Appeal finds it to be proven that the defendant intentionally shot at the bear and inflicted upon it unnecessary harm and suffering by hitting the bear with at least one shot, such that 22 pellets remained in its posterior and genitals. ${ }^{81}$

The Appeal Court convicts the defendant for causing the bear unnecessary suffering and dedicates more space to addressing the harm to the victim than does any other verdict. Moreover, the prosecutor extended the indictment for the appeal case, making this the only verdict where the reported indictment includes a separate point charging the defendant with causing the bear "unnecessary suffering," breaching the NDA § 15. The changed indictment might explain the increased emphasis on the bear's suffering, while the missing or limited evaluations in other verdicts of the harm to the victims may stem from disregard of this in the indictments. Graver ${ }^{82}$ indeed states that due to the principle of hearing both sides of a case, judges predominantly base their verdicts on what the parties present during the trial, where the parties have a chance to contradict each other's arguments. If the indictments are as crucial for acknowledging the victims' suffering as it may seem, it indicates that the prosecutors' representations of the (attempted) theriocides are highly influential in the discourse order of the verdicts. Moreover, as shown above, the bear is the only victim acknowledged as an individual being, also by the Appeal Court, which might have led the judges to consider his suffering more than in the other cases. This demonstrates the importance of courts acknowledging animals as individuals and victims.

Contrary to the bear and wolf who were hurt but not killed immediately, the verdicts do not consider the suffering of the wolf shot during the elk hunt (c2) at all. The comment that he left blood trails for kilometers is the only information provided to make any assumptions regarding his suffering, while the verdicts from the two above cases describe where the bullets hit, and the physical effects on the wolf of such a shot. In

\footnotetext{
80 THEDM-2012-51106, p. 5, my translation.

81 LE-2012-108373, p. 6, my translation and emphasis.

82 GRAVER, "Vanlig juridisk metode?... " cit. p. 167.
} 
the current case, however, the Appeal Court concludes that it "was a matter of coincidence that the shot did not hit as intended," ${ }^{83}$ while in the other cases the shooters are regarded as portraying bad hunting judgment by using unsuitable ammunition and shooting despite improper sight of the victim. Furthermore, the Appeal Court sees it as mitigating that the wolf was not killed, contrary to the other cases, where the defendants were reprimanded for the unsuccessful shots causing the victims unnecessary suffering by not killing them immediately. Seemingly, animal welfare was completely outside the Appeal Court's consciousness in this case, perhaps because it was also ignored by the parties during the trial.

This study confirms Sollund's finding that for courts adjudicating cases of large predator theriocides "... being killed is not regarded as harm — what matters is how they are killed." 84 That is if they consider the victim's suffering at all. However, it is to be expected that the courts do not problematize the victims' loss of life in these cases, since killing animals is generally allowed in Norwegian law, as long as it is done by certain methods. ${ }^{85}$ In Mæhle's words: "The courts are required to use the law in force as their basis, not to make in-depth evaluations of the validity of the value premises of the law in force." 86 The illegality of the (attempted) theriocides is (at least mainly) that the defendants killed the victims of critically endangered species without approval, breaching environmental legislation. This leads the judges to see the (attempted) theriocides as crimes against biodiversity rather than against individual animals. This also explains their focus on the victims' DNA as a possible aggravating circumstance, rather than their intrinsic value. Moreover, what the intrinsic value in the AWA entails in practice is unclear. Ellefsen ${ }^{87}$ analyzed the legislative process leading up to the AWA and concluded that its acknowledgment of intrinsic value is merely symbolic; it did not signal any actual change in animals' legal status.

\footnotetext{
${ }^{83}$ LE-2019-148163, P. 5, my translation.

${ }^{84}$ SOLLUND, "The Animal Other..." cit. p. 92, emphasis original.

${ }^{85}$ ANIMAL WELFARE ACT, cit., $\S 12$.

${ }^{86}$ SYNNE SAETHER M/EHLE, "Gjelder det andre regler for rettslig argumentasjon i rettsdogmatikken enn for domstolene? " [Do different rules apply to legal argumentation in legal dogmatics than to the courts?], Jussens Venner 39, 5-6, p. 340. My translation. <doi: 10.18261/ISSN1504-3126-2004-05-06$04>$.

${ }^{87}$ RUNE ELLEFSEN, Ny dyrevelferdslov: Beskyttes dyr eller næring?: Interessekonflikt og motstridende syn på dyrs status i lovprosessen forut for dyrevelferdsloven [New animal welfare act: Are animals or industry protected?]. Master thesis, University of Oslo, 2009. <https://www.duo.uio.no/handle/10852/22579>.
} 


\section{3. "Humane euthanasias"}

A couple of words used by the courts to describe the killings are worth dwelling on. The Appeal Court uses both of them to renarrate the shooting of the bear: "He (...) fired shot no. 2 to carry out a 'humane euthanasia' of the bear." 88 The word "euthanasia" was also used in an excerpt from a b1-verdict earlier, and it is uttered in several other verdicts. It has a legitimizing and concealing effect when used to portray the (attempted) illegal theriocides. In Norwegian, the word (avlivning) is strongly associated with veterinarians, describing how they "end the suffering" of sick animals. ${ }^{89}$ Veterinarians' "euthanasia" is far from the (attempted) illegal theriocides described in the cases analyzed here. Using the word to describe such killings is inappropriate, as in this example regarding the wolf heavily wounded during the fox hunt: "He then got his other gun that he was carrying, because he had more cartridges for it, and euthanized the wolf." "90 While reprimanding him for the first shot, the court here frames the subsequent shots in a mitigating way, as though the theriocider helped the wounded wolf, whom he indeed left to suffer for hours. As Jepson states regarding describing killing of animals as euthanasia, it "deflects the focus of the discourse away from motivations for the killing (...) and toward the supposed compassion of the agent. Thus, the human agents of the killing are cast in a benign light, regardless of their reasons for taking a life." 91

In the excerpt above, the word "humane" is coupled with "euthanasia" to describe the second shot at the bear, exemplifying a collocation-pattern of co-occurrence ${ }^{92}$-in the verdicts. The word "humane" 93 is frequently coupled with "euthanasia" or "hunting," as in several of the excerpts presented throughout the analysis. Oxford Lexico suggests numerous synonyms for "humane," all of them positive adjectives such as "compassionate," "kind," and "lenient," surely inappropriate for the (attempted) theriocides. By coupling the word "humane" with "euthanasia" (or other words for

\footnotetext{
88 LE-2012-108373, p. 5, my translation and emphasis.

${ }^{89}$ According to Jepson, the English term "euthanasia" is derived from and associated with killings of human patients to alleviate their pain and suffering, and when used regarding animals it loses its reference to such a motive: JILL JEPSON, "A Linguistic Analysis of Discourse on the Killing of Nonhuman Animals", in Society \& Animals 16, no. 2, 2008. (pp. 127-48). $<$ doi:10.1163/156853008X291426>. In Norwegian, the word is still strongly associated with killings performed by veterinarians, although it is evidently also used for other more "unkind" killings.

90 TSOST-2014-168573, p. 50, my translation and emphasis.

91 JEPSON, "A Linguistic Analysis..." cit. p. 139.

92 FAIRCLOUGH, Analysing Discourse, cit. p. 131.

93 "Human(t)" in Norwegian.
} 
theriocide), the killings are presented in a positive way, as good-natured actions. As Podosky says: "Given the nature of the word humane concerns morality, its application by a speaker can induce a belief in a listener that something is moral or permissible, even when in fact it may not be." 94 Moreover, the word humane is an extension of "human", portraying human traits in general as compassionate. This conceals obvious evidence to the contrary of how humans treat nature, animals, and other humans in inferior positions.

\section{CONCLUDING REMARKS}

It is evident that the hegemonic problem definition of the (attempted) theriocides in the verdicts is their breach of species conservation principles. If describing victims and harm caused by the crimes, the discourse represented is one of species conservation, highly focused on genetics and reproduction. This represents an environmental justice perspective that dominates the verdicts, rather than a species justice perspective. The focus is on preserving nature and the animals living there for human purposes, both now and in the future, in line with environmental justice's focus on ".. environmental rights ... as an extension of human or social rights so as to enhance the quality of human life, now and in the future." 95 The focus on genetics and species survival is likely also motivated by commitments to the Bern Convention and a transnational agreement with Sweden. Regardless, the verdicts' species conservation discourse portrays animals as elements to be managed by humans. This represents a highly anthropocentric conception of humans as managers of the globe, with a parallel to Christianity's positioning of humans as responsible for and entitled to protect and harvest from nature. ${ }^{96}$

The courts do not acknowledge the victims' intrinsic value, accorded to them in the AWA. Nevertheless, a majority of the verdicts do to some extent comment on the harm caused to the victims, seeing it as either "humane," as they were killed straight away, or aggravating the sentence if not. These evaluations reflect an acceptance of killing

\footnotetext{
94 PAUL-MIKHAIL PODOSKY, "A Linguistic Method of Deception: The Difference Between Killing Humanely and a Humane Killing", in Journal of Animal Ethics 9, no. 1, 2019. p. 80, $<$ doi:10.5406/janimalethics.9.1.0076>.

${ }^{95}$ WHITE, "The Foundations of..." cit. p. 27.

${ }^{96}$ e.g. ANDREW LINZEY, "Is Christianity Irredeemably Speciesist?", in Susan J. Armstrong and Richard G. Botzler (eds.), The Animal Ethics Reader. Taylor \& Francis. New York, 2016. (3rd Edition), (pp. 294$300)$.
} 
animals in general, as long as it is conducted in certain ways, as well as an understanding that theriocides pose no harm to the individual victims so long as they die immediately. Thus, the courts, as authoritative bodies, uphold and reproduce the general acceptance of theriocides in Western societies. However, this must be understood according to the judges' role-they must adhere to legal principles. As long as the (attempted) theriocide is carried out in a legal manner, the courts have limited room to see the loss of life for the animal victim as an aggravating factor. The recontextualizing principles of verdicts largely limit courts to evaluate whether the (attempted) theriocides were/would have been detrimental to the species' survival or not, and whether they were conducted "humanely." They could nevertheless have acknowledged the victims as such.

Not even in all cases where the victims were wounded is their suffering mentioned, confirming that even this limited version of an animal welfare discourse is in the outskirts of the discourse order. It is questionable whether this discourse upholds any form of species justice, even with the broad definition introduced here, as the individual animal victims are not acknowledged as such, and the compassion for their well-being is limited to how quickly they die. A potential exception is the bear shot in self-defense, whom the Appeal Court acknowledges as an individual being, although with a personality considered problematic. This case illustrates the importance of acknowledging animals as victims, since this is the verdict where the victim's suffering is evaluated most. The defendant in this case is also convicted for causing the victim suffering, seemingly following the prosecutor's changed indictment. This strengthens an impression that prosecutors are not only influenced by the courts' discourse order, but also influence it.

The verdicts' reproduction of anthropocentric and speciesist discourse influences the future discourse order of the large predator theriocides, and theriocides in general, both inside and outside the courts. They signal to police which perceptions of animal victims are valid and which are not in the judicial discourse order and may influence the general public by being communicated by the media. Perhaps most importantly, the discourses acknowledged in the verdicts are crystallized as precedent and part of the discourse order on which the prosecutors base new indictments and judges base new verdicts. In this way, the judges reproduce the discourse order, and the legal 
"discursive agency" to acknowledge animal victims and emphasize their suffering may be increasingly limited.

\section{BIBLIOGRAPHY}

BEIRNE, Piers. "Animal Rights, Animal Abuse and Green Criminology", in Piers Beirne and Nigel South (eds.), Issues in Green Criminology, Willan Publishing. Cullompton, 2007, (pp. 55-83).

BEIRNE and Piers. "Theriocide: Naming Animal Killing", in International Journal for Crime, Justice and Social Democracy 3, no. 2, 2014. (pp. 49-66). $<$ doi:10.5204/ijcjsd.v3i2.174>.

BERŪKŠTIENĖ, Donata. "Legal Discourse Reconsidered: Genres of Legal Texts", in Comparative Legilinguistics 28, 2016. (pp. 92-119). <doi:10.14746/cl.2016.28.5>.

BRISMAN, Avi and SOUTH, Nigel. "Green Criminology and Environmental Crimes and Harms", in Sociology Compass 13, no. 1, 2019. (pp. 1-12). $<$ doi:10.1111/soc4.12650>.

CHRISTIE, Nils. "The Ideal Victim", in Ezzat A. Fattah (ed.), From Crime Policy to Victim Policy: Reorienting the Justice System, Palgrave Macmillan UK. London 1986. (p. 17-30). <doi:10.1007/978-1-349-08305-3_2>.

ELLEFSEN, Rune. Med lov til å pine: Om bruk og beskyttelse av dyr [With license to torment: On use and protection of animals]. Fritt forlag / Inspirator forlag. Oslo, 2013.

ELLEFSEN, Rune. Ny dyrevelferdslov: Beskyttes dyr eller næring?: Interessekonflikt og motstridende syn på dyrs status i lovprosessen forut for dyrevelferdsloven [New animal welfare act: Are animals or industry protected?]. Master thesis, University of Oslo, 2009. <https://www.duo.uio.no/handle/10852/22579>.

FAIRCLOUGH, Norman. Analysing Discourse: Textual Analysis for Social Research. Routledge. London, 2003.

FIGARI, Helene and SKOGEN, Ketil. "Social representations of the wolf", in Acta Sociologica 54, no. 4, 2011. (pp. 317-332). $<$ doi:10.1177/0001699311422090>.

FRANCIONE, Gary L. Animals as Persons: Essays on the Abolition of Animal Exploitation. Columbia University Press. New York, 2008. 
GRAVER, Hans Petter "Vanlig juridisk metode? Om rettsdogmatikken som juridisk sjanger" [Ordinary legal method? On legal dogmatics as a legal genre], Tidsskrift for Rettsvitenskap 121, 2, 2008. pp. 149-178. <doi: 10.18261/ISSN1504-3096-2008-02-01>

INGEBRIGTSEN, Espen. "Talepresentasjon i straffedommer" [Speech presentation in penal sentences], in Tidsskrift for Rettsvitenskap 132, 5, 2019. (pp. 443490). <doi: 10.18261/issn.1504-3096-2019-05-02>

JEPSON, Jill. "A Linguistic Analysis of Discourse on the Killing of Nonhuman Animals", in Society \& Animals 16, no. 2, 2008. (pp. 127-48). $<$ doi:10.1163/156853008X291426>.

JØRGENSEN, Marianne Winther and PHILLIPS, Louise. Diskursanalyse som teori og metode [Discourse analysis as theory and method]. Roskilde Universitetsforlag. Fredriksberg, 1999.

KJUS, Audun, "Homo narrans i strafferetten" [Homo narrans in criminal law], in Kritisk Juss 32, 3, 2006. (pp. 254-258). <doi: 10.18261/ISSN2387-4546-2006-03-08> LARSEN, Guri. "Dyr Og Natur Som Menneskets Eiendom" [Animals and Nature as Humans' Property], in Materialisten 41, no. 3, 2014. (pp. 27-45).

LAUGERUD, Solveig. "Common Sense, (Ab)Normality and Bodies in Norwegian Rape Verdicts", in NORA - Nordic Journal of Feminist and Gender Research 28, no. 1, 2020. (pp. 18-29). <doi:10.1080/08038740.2019.1697748>.

LIBERG, Olof, CHAPRON, Guillaume, WABAKKEN, Petter, PEDERSEN, Hans Christian, HOBBS, N. Thompson and SAND, Håkan. "Shoot, Shovel and Shut up: Cryptic Poaching Slows Restoration of a Large Carnivore in Europe", in Proceedings of the Royal Society B: Biological Sciences 279, no. 1730, 7 March 2012. (pp. 910-15).

LIE, Martine S. B. and SOLLUND, Ragnhild. "Speciesism and Theriocide", in Avi Brisman, Eamonn Carrabine and Nigel South (eds.) The Routledge Companion to Criminological Theory and Concepts. Routledge. Abingdon, 2018. (pp. 386-90). <doi:10.4324/9781315744902-86>.

LINZEY, Andrew. "Is Christianity Irredeemably Speciesist?", in Susan J. Armstrong and Richard G. Botzler (eds.), The Animal Ethics Reader. Taylor \& Francis. New York, 2016. (3rd Edition), (pp. 294-300). 
MCCLANAHAN, Bill and BRISMAN, Avi. "Green Criminology for Social Sciences: Introduction to the Special Issue", in Social Sciences 9, no. 10, 2020. (pp. 14). <doi:10.3390/socsci9100170>.

MÆEHLE, Synne Sæther. "Gjelder det andre regler for rettslig argumentasjon i rettsdogmatikken enn for domstolene?" [Do different rules apply to legal argumentation in legal dogmatics than to the courts?], Jussens Venner 39, 56, 2004. (pp. 329-342). <doi: 10.18261/ISSN1504-3126-2004-05-06-04> PODOSKY, Paul-Mikhail. "A Linguistic Method of Deception: The Difference Between Killing Humanely and a Humane Killing", in Journal of Animal Ethics 9, no. 1, 2019. (pp. 76-83). <doi:10.5406/janimalethics.9.1.0076>.

RÄIKKÖNEN, Jannikke, VUCETICH, John A., VUCETICH, Leah M., PETERSON, Rolf O. and NELSON, Michael P. "What the Inbred Scandinavian Wolf Population Tells Us about the Nature of Conservation", in PLOS ONE 8, no. 6, 2013, (pp. 1-7). <doi:10.1371/journal.pone.0067218>.

ROVDATA. "Bjørn - Bestandsstatus [Bear - Population status]". $<$ https://rovdata.no/Brunbj\%C3\%B8rn/Bestandsstatus.aspx> [Retrieved 10.6.2021].

ROVDATA. "Ulv - Bestandsstatus [Wolf - Population status]". $<$ https://rovdata.no/Ulv/Bestandsstatus.aspx> [Retrieved 10.6.2021].

SINGER, Peter. Animal Liberation. Thorsons. London, 1991.

SKREDE, Joar. Kritisk Diskursanalyse [Critical Discourse Analysis]. Cappelen Damm akademisk. Oslo, 2017.

SOLLUND, Ragnhild. "A Comment to Gary Francione: Animal Rights versus Animals as Property and Nature", in Erika Andersson Cederholm, Amelie Björck, Kristina Jennbert and Ann-Sofie Lönngren (eds.), Exploring the Animal Turn: Human-Animal Relations in Science, Society and Culture. Lund University, 2016. (pp. 73-87).

SOLLUND, Ragnhild. "Introduction: Critical Green Criminology — An Agenda for Change", in Ragnhild Sollund (ed.) Green Harms and Crimes: Critical Criminology in a Changing World. Palgrave Macmillan UK. Basingstoke, 2015. (pp. 1-26). <doi:10.1057/9781137456267>.

SOLLUND, Ragnhild. "Speciesism as Doxic Practice Versus Valuing Difference and Plurality”, in Rune Ellefsen, Ragnhild Sollund and Guri Larsen (eds.), Eco- 
Global Crimes: Contemporary Crimes and Future Challenges. Ashgate, Farnham, 2012. (pp. 91-115).

SOLLUND, Ragnhild. "The Animal Other: Legal and Illegal Theriocide", in Matthew Hall, Jennifer Maher, Angus Nurse, Gary Potter, Nigel South, and Tanya Wyatt (eds.), Greening Criminology in the 21st Century: Contemporary Debates and Future Directions in the Study of Environmental Harm. Routledge. London, 2017. (pp. 79-99).

SOLLUND, Ragnhild. "Wildlife Management, Species Injustice and Ecocide in the Anthropocene", in Critical Criminology 28, no. 3, 2020. (pp. 351-369). $<$ doi:10.1007/s10612-019-09469-1>.

SOLLUND, Ragnhild. "With or without a License to Kill: Human-Predator Conflicts and Theriocide in Norway", in Avi Brisman, Nigel South and Rob White (eds.) Environmental Crime and Social Conflict. Contemporary and Emerging Issues. Ashgate, Farnham 2016. (pp. 95-124).

SOUTH, Nigel. "Green Criminology: Reflections, Connections, Horizons", in International Journal for Crime, Justice and Social Democracy 3, no. 2, 2014. (pp. 5-20). <doi:10.5204/ijcjsd.v3i2.172>.

TØNNESEN, Morten. "Menneskeveldet: antropocen - menneskets tidsalder" [The human reign: the Anthropocene - the era of humans], in Ragnhild Aslaug Sollund, Guri Larsen, and Morten Tønnesen (eds.), Hvem er villest i landet her?: råskap mot dyr og natur i antropocen, menneskets tidsalder.

Scandinavian Academic Press. Oslo, 2013. (pp. 47-56).

WHITE, Rob. "Green Victimology and Non-Human Victims", in International Review of Victimology 24, no. 2, 2018. (pp. 239-55). $<$ doi:10.1177/0269758017745615>.

WHITE, Rob. "The Foundations of Eco-Global Criminology", in Rune Ellefsen, Ragnhild Sollund, and Guri Larsen (eds.), Eco-Global Crimes: Contemporary Problems and Future Challenges. Routledge. Farnham, 2012. (pp. 15-33).

\section{Legislation and verdicts}

International treaties

COUNCIL OF EUROPE. Convention on the Conservation of European Wildlife and Natural Habitats, ETS No.104 (1979). 
<https://www.coe.int/en/web/conventions/full-list/-/conventions/treaty/104> [Retrieved 10.3.2021].

Domestic legislation

ANIMAL WELFARE ACT, LOV-2009-06-19-97. Translated version by Ministry of Agriculture and Food. <https://www.regjeringen.no/en/dokumenter/animalwelfare-act/id571188/> [Retrieved 2.2.2021].

NATURE DIVERSITY ACT, LOV-2009-06-19-100. Translated version by Ministry of the Environment. <https://www.regjeringen.no/en/dokumenter/nature-diversityact/id570549/>. [Retrieved 5.3.2021].

Judicial decisions

HR-2016-1857-A

LE-2012-108373

LE-2015-83191

LE-2016-182913

LE-2017-6392

LE-2019-148163

THEDM-2012-51106

TOVRO-2012-30478

TSGUD-2019-69611

TSOST-2014-168573

TSOST-2016-183971 